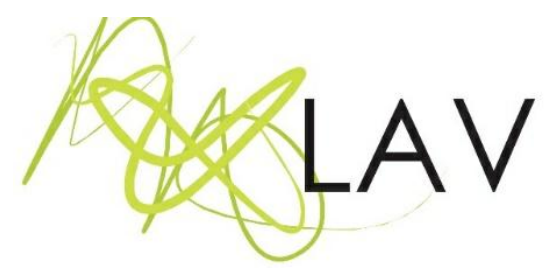

\title{
Anarquismo e infância: a literatura anarquista para crianças
}

Anarchism and childhood: anarchist literature for children

\author{
Sílvio Donizetti de Oliveira Galloi \\ Universidade Estadual de Campinas \\ Olivia Pires Coelhoii \\ Universidade Estadual de Campinas \\ Rafael Moraes Limongelliiii \\ Universidade Estadual de Campinas \\ Renato Mendesiv \\ Universidade Estadual de Campinas
}

\section{Resumo}

Este artigo discute a produção de materiais literários por coletivos e editoras anarquistas, concentrando-se nos livros destinados às crianças. Investe em uma metodologia de discussão sobre três livros infantis produzidos por anarquistas, sendo: A Cura (Brasil, 2015), A Rule is to Break (Estados Unidos, 2012) e Animal Squat (Inglaterra, 2019) e contextualiza a experiência política e militante da difusão de parte desse material no Brasil, através do Laboratório de Educação Anarquista (LEA). Discorre acerca das concepções de literatura infantil e de criança/infância, defendendo um posicionamento político antiadultocêntrico.

Palavras-chave: Literatura infantil, Literatura anarquista, Anarquismo, Infância.

\begin{abstract}
This article discusses the production of literature by anarchist collectives and publishers, focusing on children's books. It invests in a discussion methodology of three children's books produced by anarchists, namely: A Cura (Brazil, 2015), A Rule is to Break (United States, 2012) and Animal Squat (England, 2019). The political and militant experience of disseminating part of this material in Brazil through the Anarchist Education Laboratory (LEA) is also contextualized. Lastly, the conceptions of children's literature and child / childhood are discussed, defending a political position of anti-adultcentrism.
\end{abstract}

Keywords: Children's literature, Anarchist literature, Anarchism, Childhood. 


\section{Literatura "menor" para os "menores"}

Gilles Deleuze e Félix Guattari nos inspiram a pensar a literatura como experimentação da vida, no sentido de que "tem como horizonte a liberdade que a vida pressupõe para continuar sempre sua trajetória de criação de mundos, de possibilidades e de encontros" (OLIVEIRA, 2011, p. 12). Como Roland Barthes, defendemos a literatura como "uma revolução permanente da linguagem": "Entendo por literatura não um corpo ou uma seqüência de obras, nem mesmo um setor de comércio ou de ensino, mas o grafo complexo das pegadas de uma prática: a prática de escrever" (1978, p. 16).

Entendemos aqui, então, a literatura dita infantil como uma experimentação da vida, a criação de um mundo e um convite a um repertório de vastos possíveis. A literatura para crianças surge como objetivo de perpetuar os dogmas e costumes do século XVII, como modo de adestrar moralmente as crianças. Ao longo dos séculos, ela passa a ser entendida a partir das necessidades e anseios das próprias crianças, de acordo com a concepção de infância e criança presentes ou ausentes ao longo da história.

A literatura infantil surgiu no século XVII com Fenélon (1651-1715), justamente com a função de educar moralmente as crianças. As histórias tinham uma estrutura maniqueísta, a fim de demarcar claramente o bem a ser aprendido e o mal a ser desprezado. A maioria dos contos de fadas, fábulas e mesmo muitos textos contemporâneos incluem-se nessa tradição (SILVA, 2009, p. 3).

Neste momento, utilizamos o termo literatura infantil como uma defesa pela menoridade, tanto a da idade quanto a condição subversiva da linguagem proposta pelos pensadores franceses, pensando-as de maneira sinônima, na medida em que se tornam ferramentas conceituais, engajadas na criatividade, para pensar o que está à margem. "Vale dizer que 'menor' não qualifica mais certas literaturas, mas as condições revolucionárias de toda literatura no seio daquela que chamamos de grande (ou estabelecida)" (DELEUZE; GUATTARI, 1997, p. 28). Deleuze (1997, p. 122), por sua vez, trata da literatura menor como um fazer gaguejar a língua, produzindo uma "linguagem afetiva, intensiva, e não mais uma afecção daquele que fala". Concebemos a literatura infantil em modo menor como a produção de uma gagueira infantil na língua estabelecida, a produção de uma infância da língua.

Nesse registro, a criação de literatura para crianças não parte de um "forjar" a infância, mas de uma tentativa de habitar o território da linguagem "das crianças", ousar se tornar estrangeiro na própria adultice, (re)inventar-se nas linhas de fuga, nos mundos criados a partir da resistência, da negação de insistir no estabelecido. Nesse sentido, entendemos que o "maior" constituiria, entre outros aspectos, a literatura dita adulta, ou seja, a literatura que não é para crianças, isto porque o poder estabelecido em seu caráter 
adultocêntrico define os limites do que é "sério", "para valer", tangenciando a literatura infantil para o campo do menor. Não se trata, então, de forjar a infância através da literatura, mas de olhar para essas produções pelo viés da infância, não do adulto em potencial que a criança poderá ser, por intermédio da literatura. Para elucidar o conceito de adultocentrismo, dialogamos com a pesquisadora feminista Fúlvia Rosemberg:

A ciência ocidental apresenta uma postura adultocêntrica, em que aquele que é considerado o mais forte em sociedades competitivas olha para a infância como se procurasse um outro adulto, o adulto que a criança será. A biologização e naturalização da criança e do bebê, com os padrões adultos e de maturidade permeando a compreensão do desenvolvimento, retiram da infância a sua historicidade e seu potencial transformador (ROSEMBERG, 1976, p. 1476).

"Se a literatura maior busca um modelo universal, a literatura menor escava possibilidades de fugir dela, um movimento de resistência, uma potência inventiva" (COSTA; BRITO, 2018, p. 24). Nesse sentido, estamos atentos a essa potência inventiva na própria infância, nos seus signos, gestos e narrativas.

A literatura infantil tem sido relacionada a uma condição de menoridade, isto é, a uma produção literária de qualidade inferior, a qual se esgota em um projeto utilitário, pedagógico, o qualificativo infantil associa-se a um leitor previsto - a criança -, sendo que este gênero literário guarda um estreito vínculo com determinadas concepções de infância que consideram a criança como um ser em desenvolvimento, o qual necessita ser preparado para assumir seu futuro lugar na sociedade (HILLESHEIM, 2008, p. 1).

Fizemos o esforço conjunto de selecionar produções com evidente qualidade gráfica e narrativa, que se propusessem a dialogar fora de um projeto pedagógico ou utilitário e que fossem efetivamente comprometidas com a concepção de infância para além do adultocentrismo. Entendemos a infância a partir do devir e da potência, evitando conceituações e paradigmas do porvir.

Decerto que escrever não é impor uma forma (de expressão) a uma matéria, a do vivido. A literatura tem que ver, em contrapartida, com o informe, com o inacabado, como disse Gombrowicz e como o fez. Escrever é uma questão de devir, sempre inacabado, sempre a fazer-se, que extravasa toda a matéria vivível ou vivida. E um processo, quer dizer, uma passagem de Vida que atravessa o vivível e o vivido. A escrita é inseparável do devir: ao escrevermos, devimos-mulher, devimos-animal ou vegetal, devimos-molécula até devir-imperceptível (DELEUZE, 1997, p. 11).

Não resistimos em acrescentar aos devires listados por Deleuze: ao escrever, devimos-criança. A literatura infantil menor é um modo de habitar a infância da língua, devir-criança com as crianças, gaguejar com elas, para produzir uma sensibilidade comum, 
que implique na construção de pensamentos, sem caminhar para um mundo adulto como meta central.

Neste contexto, de devir e inacabamento, enquanto atravessamos a matéria vivível, propomos a construção de uma narrativa, uma forma de afirmar uma nova história para nossas histórias, afirmar um outro modo de olhar as lutas, alternar os pontos de vista, derreter os miolos do olho que tudo vê e contar a história pela potência dos debaixo: vamos contar um conjunto de experiências coletivas entre anarquistas educadores e discutiremos o contexto e o processo de curadoria de livros infantis anarquistas.

\section{Do estudo à prática: Laboratório de Educação Anarquista (LEA)}

O Laboratório de Educação Libertária (LEA) é um desdobramento do Grupo de Estudos de Pedagogia Libertária ${ }^{1}$ realizado entre 2010 e 2014, organizado junto à Biblioteca Terra Livre em São Paulo. Esse grupo de estudos constituído por anarquistas apaixonados e apaixonadas pela educação e pela liberdade, em março de 2014, passou a constituir o LEA como uma nova estratégia que estaria mais alinhada às necessidades e desejos das pessoas envolvidas.

O objetivo do LEA é propor atividades pedagógicas para crianças baseadas nos princípios anarquistas. Para isso, será necessário a produção e escrita de materiais didáticos e de apoio às práticas educativas, tais como jogos, exercícios, trabalhos manuais, músicas, histórias, teatro, etc., sempre contendo, expressando e realizando os pressupostos da educação libertária construídos e praticados teórica e historicamente por nomes como Proudhon, Bakunin, Kropotkin, Reclus, Tolstoi, Robin, Ferrer, Faure, Jacquinet, Laisant, Pelloutier, Louise Michel, entre outros nomes do anarquismo internacional. No Brasil, reivindicamos as propostas das Escolas Modernas e Racionalistas do início do século XX e o pensamento de educadores como Adelino de Pinho, Maria Lacerda de Moura, José Oiticica, João Penteado, Jaime Cubero e muitos outros. $^{2}$

Em março de 2014, o LEA organizou o I Encontro de Pedagogia Libertária do Laboratório de Educação Anarquista (LEA), realizado no Centro de Cultura Social (CCS) na cidade de São Paulo. O LEA se propôs, para além dos objetivos citados acima (produção de materiais pedagógicos, grupos de estudos, trabalhos manuais, intervenções, etc), à invenção de espaços pedagógicos anti-autoritários, procurando inventar no

\footnotetext{
1 O histórico de conversas do Grupo de Estudos de Educação Libertária se encontra em https://bibliotecaterralivre.noblogs.org/grupos-de-estudos/anarquismo-e-educacao/

2 Ver mais informações sobre o Laboratório de Educação Libertária em https://bibliotecaterralivre.noblogs.org/post/2014/03/19/laboratorio-de-educacao-anarquista-lea/
} 
presente formas de sociabilidade não autoritária e alinhada às críticas das pedagogias libertárias.

O LEA manteve reuniões e encontros de estudos, organização e produção frequentes. Os encontros realizados a princípio na Biblioteca Terra Livre e depois variando de espaços, eram divididos entre várias frentes de ação, tais como:

a) frente de estudos: para alimentar as práticas é preciso continuar os estudos e, deste modo, o LEA manteve seus encontros de estudos sobre textos clássicos da pedagogia libertária, abrindo esses encontros para o público em geral, em reuniões agendadas e divulgadas amplamente sobre algum texto específico da pedagogia libertária. Nesses encontros os integrantes do Laboratório conduziam a exploração conceitual dos textos abrindo para debater com as pessoas que se interessavam pela temática;

b) frente editorial: responsável pela tradução de títulos, escrita de novos livros, revisão de textos, ilustração, administração de contatos entre outros grupos colaboradores, com objetivo de produzir livros para crianças e seus adultos. Podemos destacar alguns dos processos destes livros que apresentam táticas diversas de editoração: O Dragão do Reino de $\mathrm{Orb}^{3}$, do anarquista italiano Federico Zenoni, que foi traduzido pelo LEA e publicado pela Biblioteca Terra Livre.

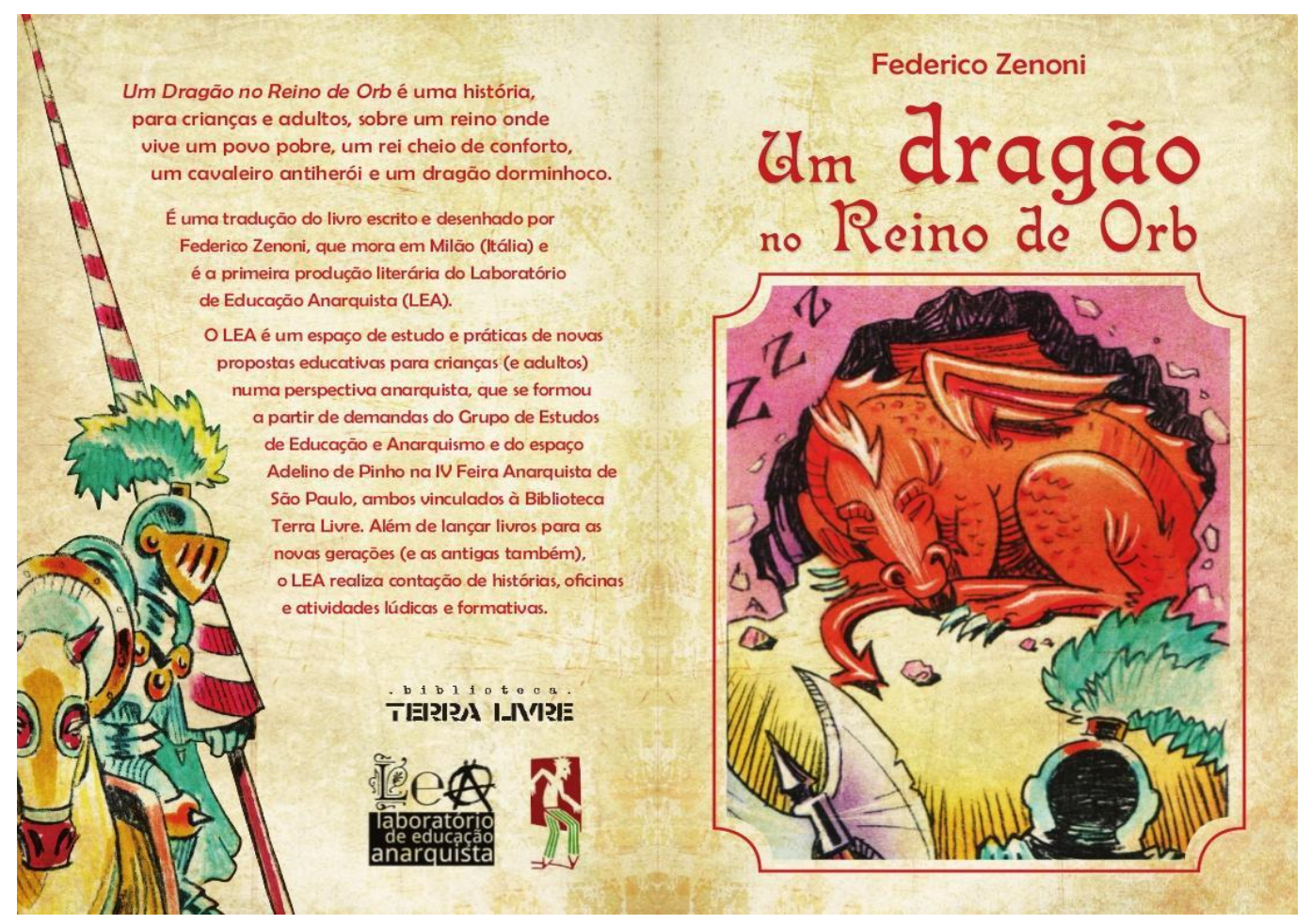

Figura 1: O Dragão do Reino de Orb

Fonte: Disponível em: <https://bibliotecaterralivre.noblogs.org/editora/um-dragao-noreino-de-orb/>

${ }^{3}$ Disponível em https://bibliotecaterralivre.noblogs.org/editora/um-dragao-no-reino-de-orb/ 
Outro livro que seria importante destacar tem um processo de produção completamente diferente, é o livro Um $A B C$ da Anarquia ${ }^{4}$, também publicado pelo LEA junto a Biblioteca Terra Livre, um livro composto por muitas mãos. Neste livro, há 26 conceitos relacionados com os anarquismos, um conceito para cada letra do alfabeto e para cada conceito existe uma ilustração diferente, as ilustrações foram feitas por 13 camaradas anarquistas de diferentes partes do mundo. No livro ainda há a indicação e estímulo que as pessoas se apropriem da ideia e façam elas mesmas os seus próprios outros $A B C$ da anarquia, inclusive em parceria com o LEA (caso elas queiram).

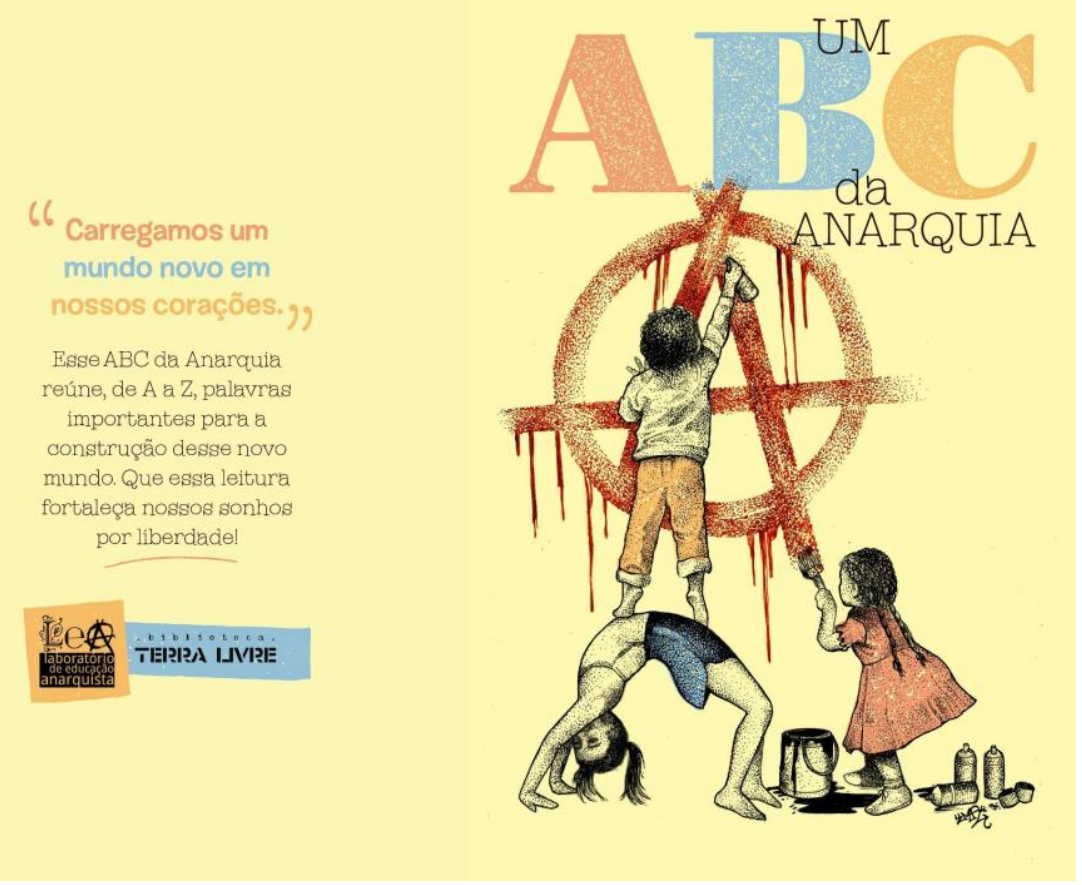

Figura 2: Um $A B C$ da Anarquia

Fonte: Disponível em:<https://bibliotecaterralivre.noblogs.org/editora/um-abc-daanarquia/>

Outra publicação importante de comentar trata-se do livro $A$ Cura $^{5}$, do anarquista e militante do LEA, Allan Freitas. Essa linha editorial do LEA passou a publicar histórias e narrativas pensadas pelos próprios membros do Laboratório, sendo o livro A Cura um entre outros títulos publicados neste sentido, com autoria de membros do próprio grupo.

\footnotetext{
${ }^{4}$ Disponível em https://bibliotecaterralivre.noblogs.org/editora/um-abc-da-anarquia/

${ }^{5}$ Disponível em https://bibliotecaterralivre.noblogs.org/editora/a-cura/
} 

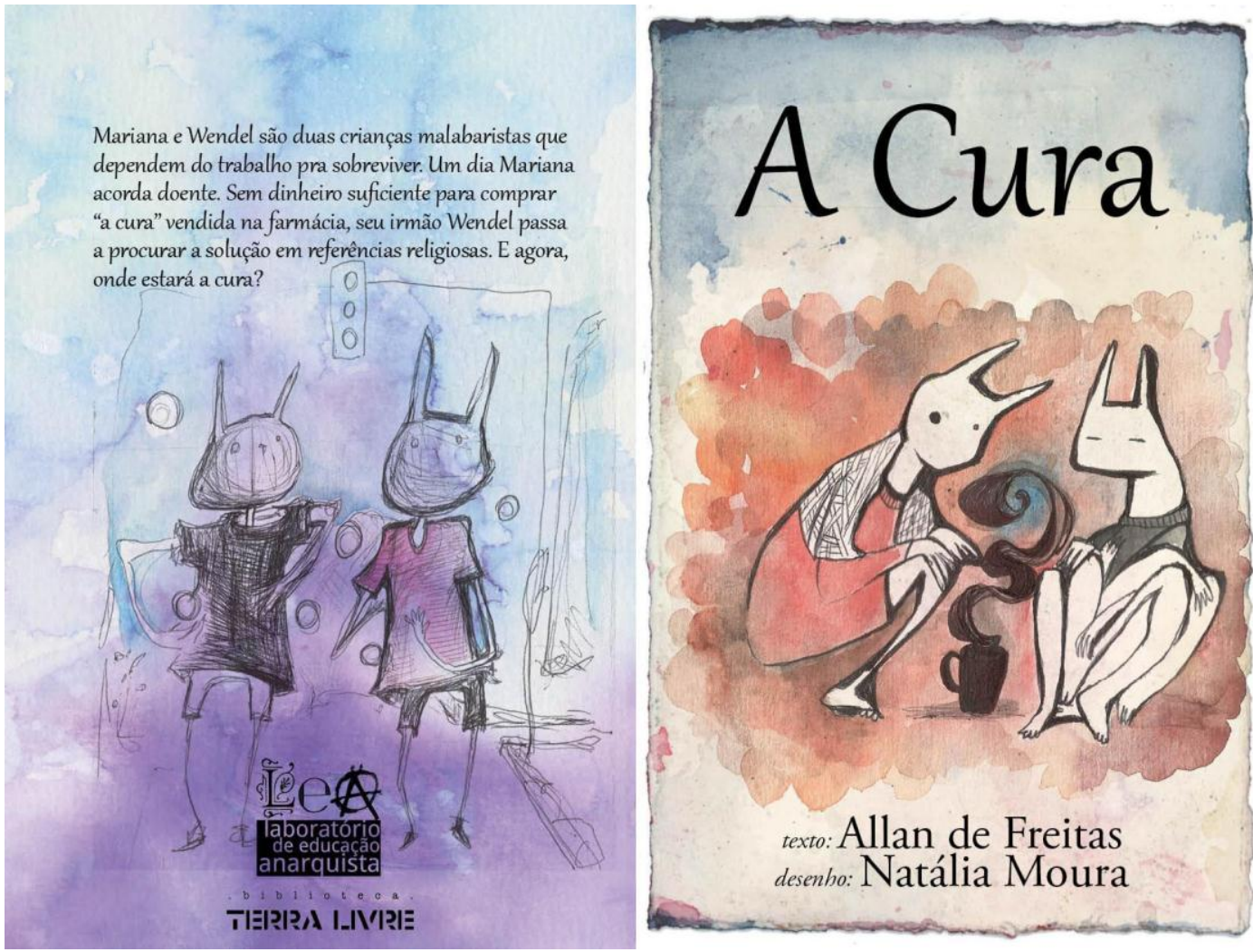

Figura 3: A Cura

Fonte: Disponível em: <https://bibliotecaterralivre.noblogs.org/editora/a-cura/>

c) frente de articulação com outros movimentos: procurou estabelecer frentes de apoio mútuo com outras organizações da luta popular, pensando em intervenções e criações de políticas de base mais continuadas. Podemos destacar, para este texto, duas ações importantes realizadas pelo LEA.

A primeira ação foi a articulação com a Favela do Moinho. Tal articulação do LEA com o movimento Moinho Vivo teve uma duração contínua, com encontros periódicos na comunidade, em que foram realizadas algumas das atividades que o LEA estava desenvolvendo (como contação de histórias, atividades manuais de pintura vegetal, desenvolvimento de bonecos revolucionários, etc), ações realizadas junto a associação de moradores da comunidade Moinho Vivo, que tem um longo percurso de resistência, sendo uma das última favelas urbanas do centro da cidade de São Paulo.

A segunda ação se deu junto com a Feira Anarquista de São Paulo (FASP) e o desenvolvimento do Espaço Adelino de Pinho. Há muito tempo é uma questão importante na realização da Feira Anarquista de São Paulo (FASP) a inclusão de crianças e pessoas que vivem com crianças. O grupo de estudos de pedagogia libertária já realizava diversas ações em edições da FASP (antes da formação do LEA), com convocatórias 
públicas, convidava camaradas para integrarem as ações e se corresponsabilizarem pelo cuidado das crianças durante a FASP.

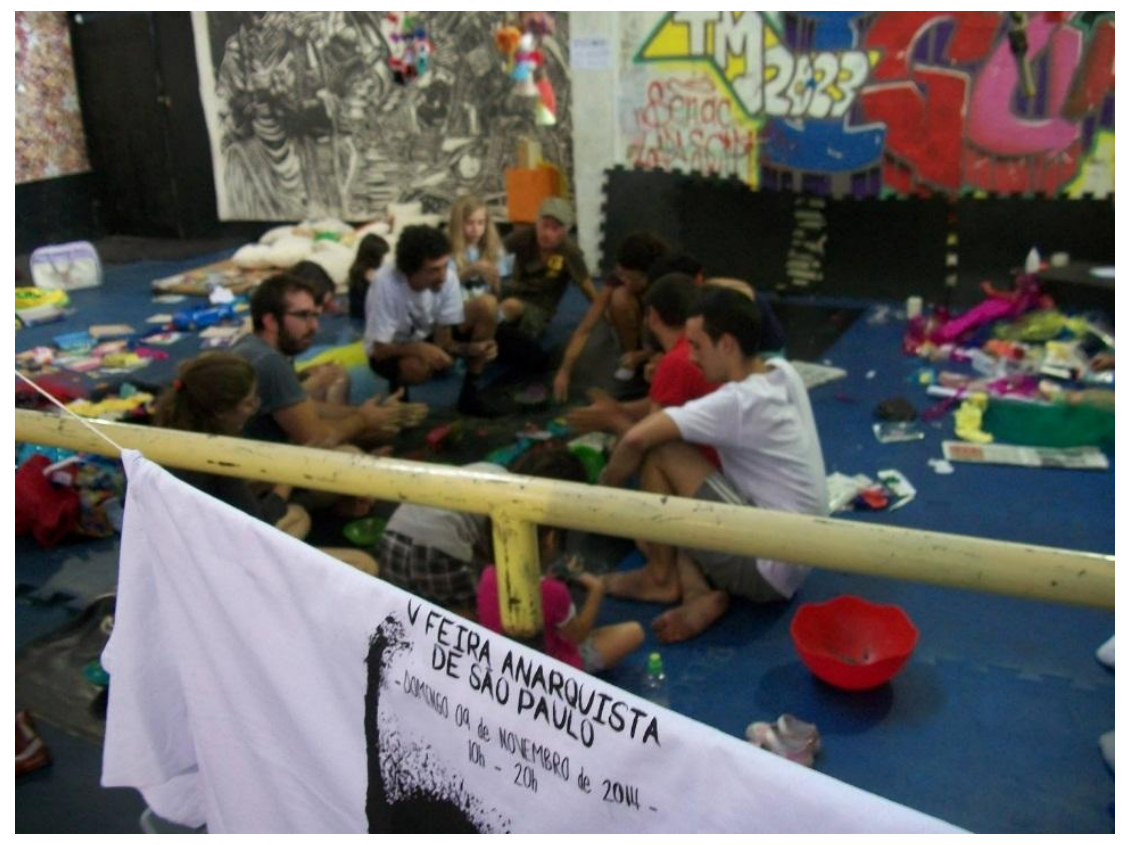

Figura 4: Espaço Adelino de Pinho. Fonte: V FASP (2014).

Esse aspecto de corresponsabilização é uma pauta muito importante para o LEA, desde que passou a coordenar de forma mais sistemática o espaço das crianças na FASP de 2014 e fundou o Espaço Adelino de Pinho em 2015.

Para nós, anarquistas, o modelo familiar burguês em que o cuidado das crianças é responsabilidade apenas dos pais e mães biológicos reproduz estruturas de exploração do trabalho não remunerado das mulheres. Essas relações familiares reproduzem o machismo, privilegiando os homens com a oportunidade de ouvir debates, participar de rodas de conversa, encontrar seus camaradas na FASP, enquanto às mulheres fica delegada a função de cuidado das crianças, impedindo-as de participar de outras atividades da FASP que não sejam direcionadas para este público. Em suas práticas comunitárias os anarquistas procuram criar crianças partilhando a responsabilidade com outras pessoas da comunidade, não apenas seus pais biológicos.

A construção de uma cultura anarquista passa pela presença e inserção das novas gerações no cotidiano militante. Se não investirmos na formação das novas gerações estaremos tornando cada vez mais distantes de nós e de nossas descendências o mundo novo que tantos almejaram muito anos antes de nós e que seguimos caminhando em sua direção (ROSA, 2015, p. 25). 


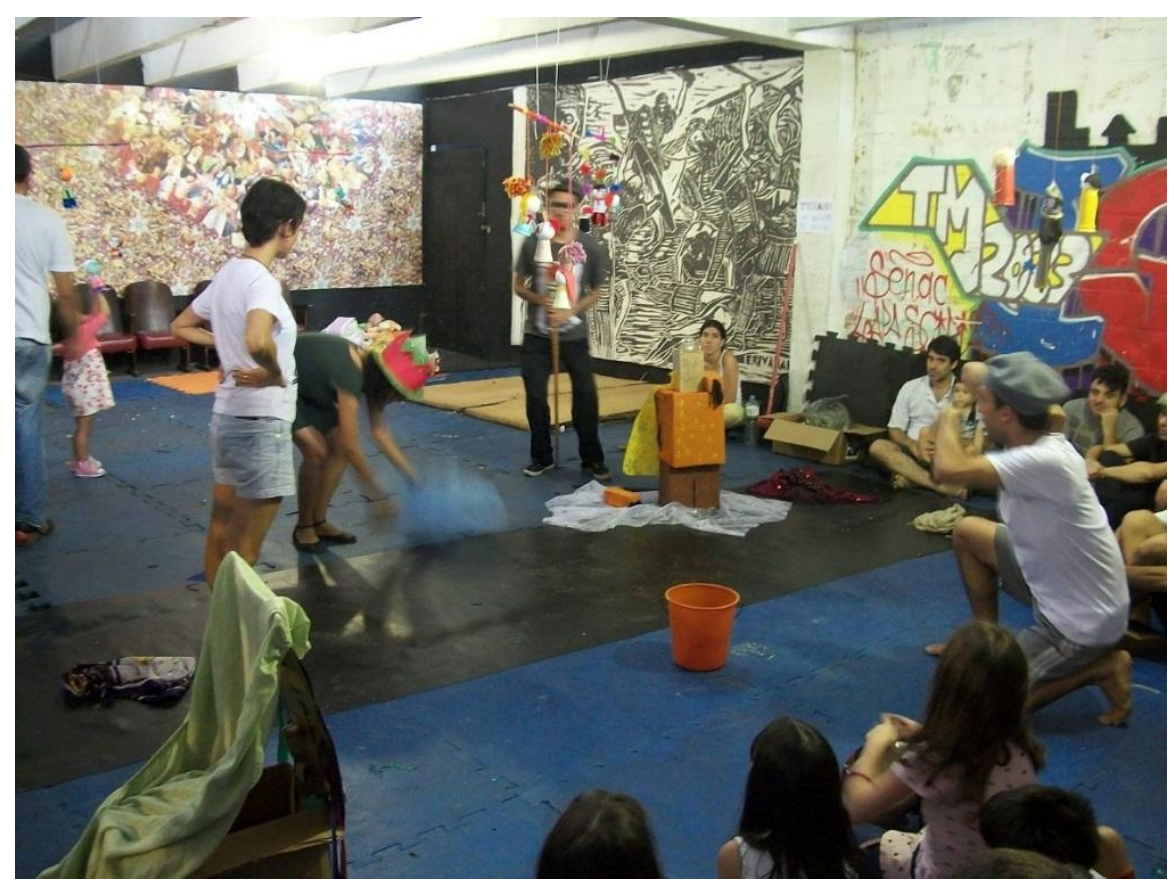

Figura 5: Teatralização do livro O Dragão do Reino de Orb no Espaço Adelino de Pinho. Fonte: V FASP (2014).

Na FASP, o Espaço Adelino de Pinho se formou como uma prática de criação de um espaço de sociabilidade anti autoritário, no qual crianças e adultos poderiam conviver e criar práticas de aprendizagem coletivas. Além das premissas ideológicas mencionadas acima, lutando contra as relações patriarcais nos cuidados com as crianças, há uma outra pauta importante para o Espaço Adelino de Pinho: a criação de uma espacialização que permita crianças e seus adultos criarem de modo autônomo e em liberdade as práticas que Ihes interessam.

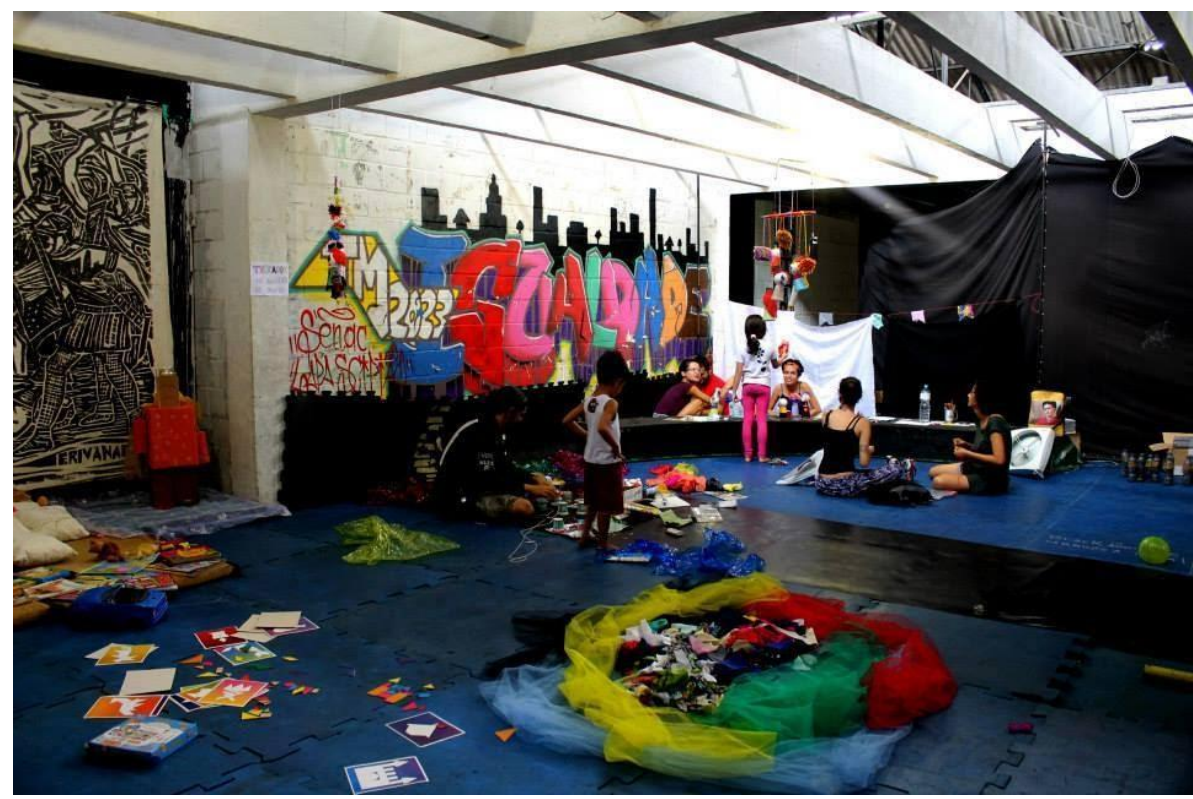

Figura 6: Espaço Adelino de Pinho Fonte: V FASP (2014). 
O Espaço Adelino de Pinho, neste sentido, atuava em duas frentes sincrônicas, por um lado as pessoas do LEA preparavam uma série de atividades programadas em horários específicos, tais como contação de histórias, peças de teatro, exibição de filmes, criação de bonecos revolucionários, pinturas coletivas, caça a tesouros, entre outras, por outro lado o espaço era pensado com dispositivos para serem acionados a qualquer momento por crianças e adultos, tais como almofadas, tecidos, canetas, papéis, brinquedos, entre outros, que permitiam uma ativação de atividades no espaço independente da programação pré-estabelecida pelo LEA.

(...) em essência o que se busca com esses espaços para e de crianças nas Feiras Anarquistas é servir de laboratório para práticas pedagógicas livres e libertárias, produzindo e testando atividades e materiais livres de preconceitos e autoritarismo, visando a transformação do sujeito, seja qual for sua idade, em produtor do próprio destino. Que todas e todos sejam autores de suas próprias vidas e possam aprender novos valores em meio ao movimento anarquista, nos espaços autônomos, nas manifestações de rua e, até quem sabe, em escolas libertárias (ROSA, 2015, p. 36).

\section{Livros infantis anarquistas}

Não pretendemos analisar os livros aqui apresentados no sentido de interpretá-los pelo binômio forma-conteúdo. Nossa intenção é construir uma espécie de arquivo de literatura infantil que nasce no contexto revolucionário das práticas anarquistas. Estabelecendo um diálogo entre as práticas anarquistas e o pensamento de Deleuze, que também como referência, podemos inferir:

É importante ter em mente que a entrada desse autor (Deleuze) na literatura não é para interpretá-la ou analisá-la. Para além dessas questões a literatura percorre o pensamento deleuzeano sempre em conexão com um problema filosófico (DIAS, 2007). Não interessa para ele o aspecto léxico da obra, mas, sobretudo, o ritmo linguístico, o revolucionário, a gagueira que ela produz na língua, os problemas que a literatura é capaz de criar (COSTA; BRITO, 2018, p. 21).

Estamos atentos aos encontros e agenciamentos produzidos a partir do contato com essa experimentação artística. No segundo semestre de 2020, realizamos a primeira curadoria de livros infantis anarquistas, com acervo brasileiro e mundial. Apresentamos os resultados no contexto da disciplina Filosofia da Educação Anarquista oferecida na Faculdade de Educação da Universidade Estadual de Campinas (UNICAMP).

A disciplina, de caráter eletivo, reuniu diversos estudantes dos cursos de Licenciatura da Universidade. Grande parte dos estudantes envolvidos não estavam familiarizados com discussões sobre anarquismo e infância, o que acabou tornando o debate muito produtivo, com muitas perguntas e provocações catalisadas pelos 
participantes. Na oportunidade, foi possível apresentar e discutir oito títulos de literatura infantil anarquista. Para compor o presente artigo, selecionamos três títulos, após um exercício de curadoria coletiva; os critérios foram: 1) selecionar livros produzidos em contextos diferentes, 2) favorecer a multiplicidade de histórias narradas e 3) priorizar produções artesanais ou de editoras independentes.

A escolha dos livros também foi pautada em um compromisso de rompimento com o pacto colonial adultocêntrico, inspirados em Santiago e Faria (2015):

$\mathrm{O}$ ato de escrever, por mais que limite a experiência humana, também abençoa vidas não abençoadas, transforma-se em uma ação política por excelência, a qual é tomada nestas páginas como possibilidade de criação de inquietações para a construção de pedagogias descolonizadoras, não adultocêntricas (2015, p. 74).

Então, ao mesmo tempo que lidamos com uma expressão artística limitada, a literatura, a palavra escrita em interlocução com as artes visuais, entendemos se tratar de um convite às inquietações, um convite ao estranho, colocando-se em posição de familiarizar o estranho e estranhar o familiar no que conhecemos, até então, pelo discurso "maior"/estabelecido acerca das crianças e de suas infâncias. Buscamos, no pacto contraadultocêntrico, valorizar produções artísticas que colaborem para o rompimento da história única sobre o infantil. "A única história cria estereótipos. E o problema com estereótipos não é que eles sejam mentira, mas que eles sejam incompletos. Eles fazem uma história tornar-se a única história" (ADICHIE, 2019, p. 4).

Negar a história única significa, aqui, construir novos fluxos, novos argumentos, novas imagens e/ou novas palavras que contemplem a multiplicidade de histórias, de vidas, de existências que defendemos enquanto anarquistas. Uma opção pelo múltiplo, por perspectivas diferentes e os jogos que elas implicam. Neste caso específico, a escolha pela multiplicidade do mundo da infância, diversas infâncias, inúmeras explorações de mundo e narrativas outras que podem proporcionar mundos outros. A partir da curadoria coletiva selecionamos, então, três materiais para discutir nesse artigo.
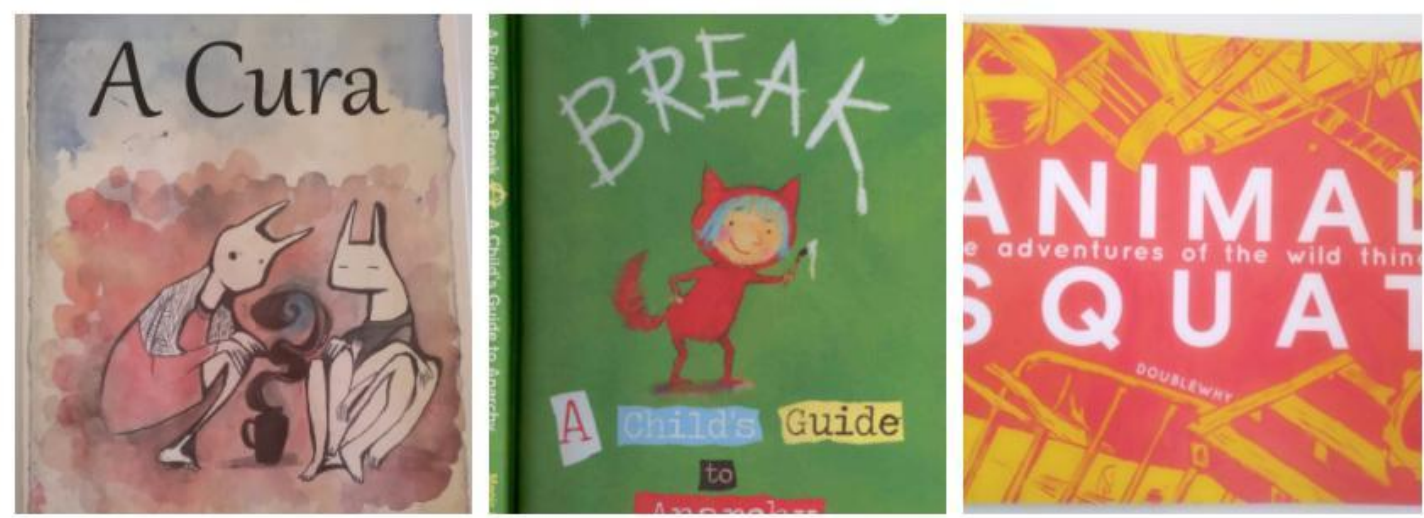

Figura 7: Livros selecionados após curadoria dos autores. Fonte: Acervo pessoal de Olivia Pires Coelho

Revista Digital do LAV - Santa Maria - vol. 14, n. 2, p. 187 - 207 - mai./ago. 2021 ISSN 1983 - 7348 http://dx.doi.org/10.5902/1983734865621 
O livro A Cura foi o primeiro material selecionado; inventado no chão latinoamericano, a história narra o cotidiano de duas crianças malabaristas, Mariana e Wendel. Foi escrito pelo anarquista e pedagogo brasileiro Allan de Freitas, ilustrado pela artista Natália Moura e publicado pela Biblioteca Terra Livre por meio do Laboratório de Educação Anarquista em novembro de 2015.

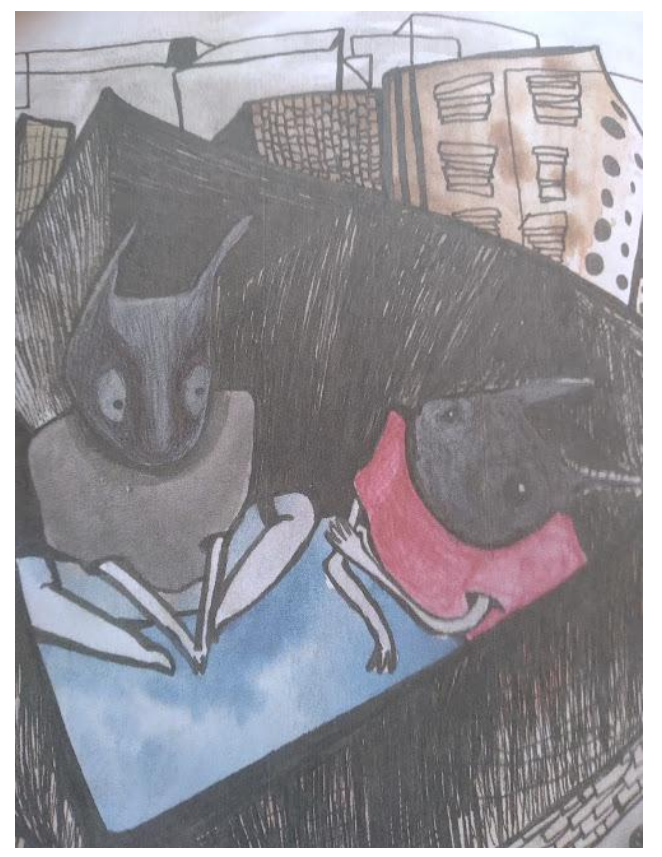

Figura 8: Os irmãos Wendel e Mariana

Fonte: Disponível em: <https://bibliotecaterralivre.noblogs.org/editora/a-cura/>

Apresenta o cotidiano, história do presente, movimento no tempo de Mariana e Wendel, crianças trabalhadoras que não convivem com um núcleo familiar parental. Moram na periferia de um grande centro urbano brasileiro, trabalham de modo autônomo e sua narrativa aborda duas questões delicadas, contraditórias e pouquíssimo exploradas na literatura infantil, ainda que seja uma realidade no Brasil6: crianças em situação de abandono familiar, responsáveis pelo próprio sustento e a temática da indústria farmacêutica.

O livro não entra em detalhes sobre a particularidade do histórico familiar de Mariana e Wendel, que são irmãos, apenas que vivem sozinhos. Não faz alusão sobre certo ou errado das estruturas familiares, concentrando-se em familiarizar o leitor com a estranheza da dinâmica de vida dos dois irmãos. Mariana, a irmã, adoece e o irmão, Wendel, investiga possíveis curas para sua doença.

\footnotetext{
${ }^{6}$ De acordo com o Instituto Brasileiro de Geografia e Estatística (IBGE): "No Brasil, em 2019, havia 38,3 milhões de pessoas com entre 5 a 17 anos de idade. Deste total, 1,8 milhão estavam em situação de trabalho infantil". Fonte:https://agenciadenoticias.ibge.gov.br/agencia-noticias/2012-agencia-de-noticias/noticias/29738trabalho-infantil-cai-em-2019-mas-1-8-milhao-de-criancas-estavam-nessa-situacao
} 
Ao se deparar com a doença da irmã, Wendel reflete: "Para quem pedir ajuda? Não tem pai, nem mãe, nem avós e nem mesmo uma tia" (2016, p. 5). Porém, a história nos convida a explorar todas as possibilidades do fora, do excêntrico, do peculiar e a conhecer, então, o mundo de Wendel e Mariana.

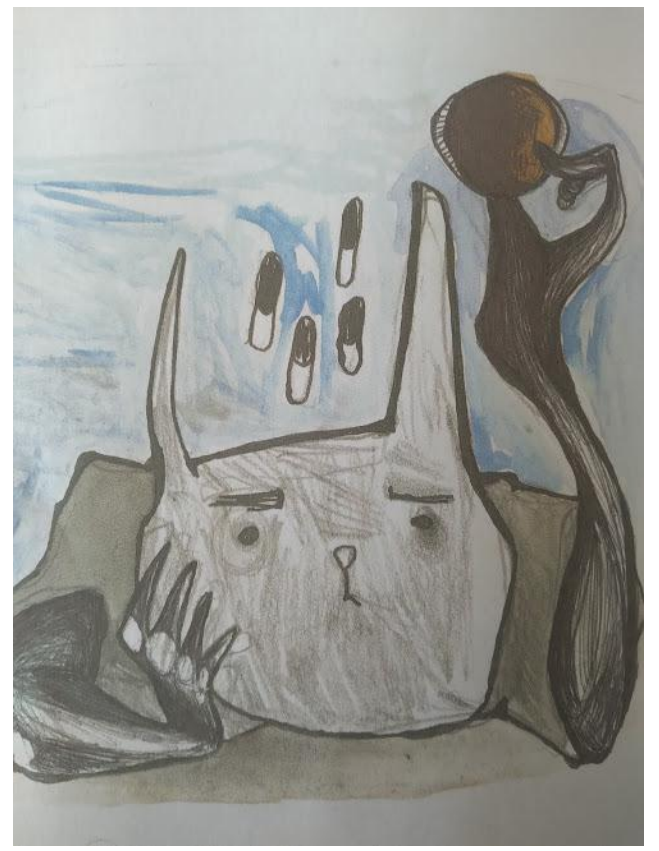

Figura 9: Wendel preocupado.

Fonte: Disponível em: <https://bibliotecaterralivre.noblogs.org/editora/a-cura/> (p. 4).

No seu percurso pela cura, Wendel decide, em primeiro lugar, visitar um farmacêutico, porém, se assusta com o custo dos remédios. Mariana, que apresenta sintomas de gripe e resfriado, está sem poder trabalhar e Wendel se ausenta dos malabares para investigar possíveis curas para a irmã. Após descobrir que o valor dos remédios na farmácia custaria todo dinheiro que receberiam durante o mês inteiro, Wendel decide investir em outras frentes.

Decidido a achar a cura, Wendel procura soluções religiosas. Visita uma vizinha evangélica, que Ihe oferece "água abençoada" por um pastor de sua igreja. Após ouvir a vizinha conversar com Deus e gritar com o diabo, Wendel leva a água para irmã, que mesmo após beber, não se sente melhor. Wendel decide visitar outra vizinha, dessa vez, católica; a outra vizinha sugere a reza de trinta e três terços para encontrar a cura. Wendel e Mariana rezam os trinta e três terços, mas seguem sem a melhora de Mariana. Após duas tentativas frustradas, Wendel decide ir ao terreiro do bairro, onde the disseram para dar um banho de pipoca em Mariana, pois Obaluaê, orixá da cura, iria Ihe livrar da doença. Para desespero dos irmãos, Mariana seguia muito doente. 


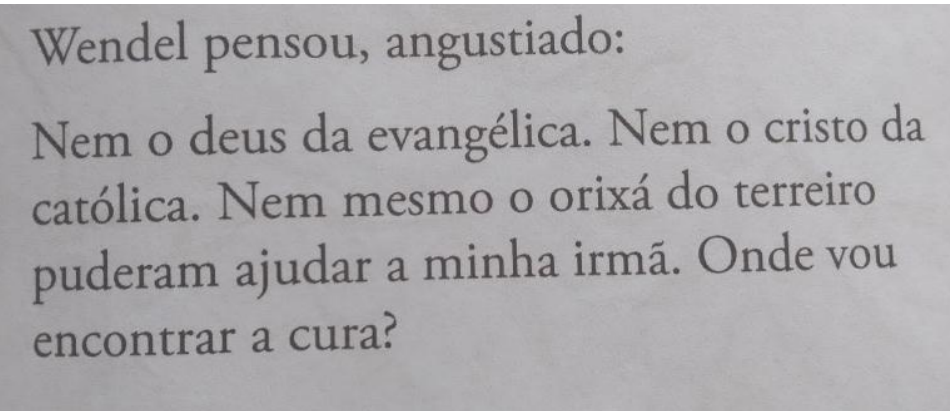

Figura 10: Livro $A$ cura

Fonte: Disponível em: <https://bibliotecaterralivre.noblogs.org/editora/a-cura/> (p. 13).

Até aqui, a história nos convidou a pensar sobre a impossibilidade de duas crianças, vivendo de forma autônoma, para conseguirem recursos financeiros ou suporte para tratar a doença de Mariana. Wendel decide apostar no conhecimento tradicional e indagar um velho morador do bairro sobre as possibilidades de cura para sua irmã. O velho Banzé, fumando um cigarro, apenas lhe diz: "alho".

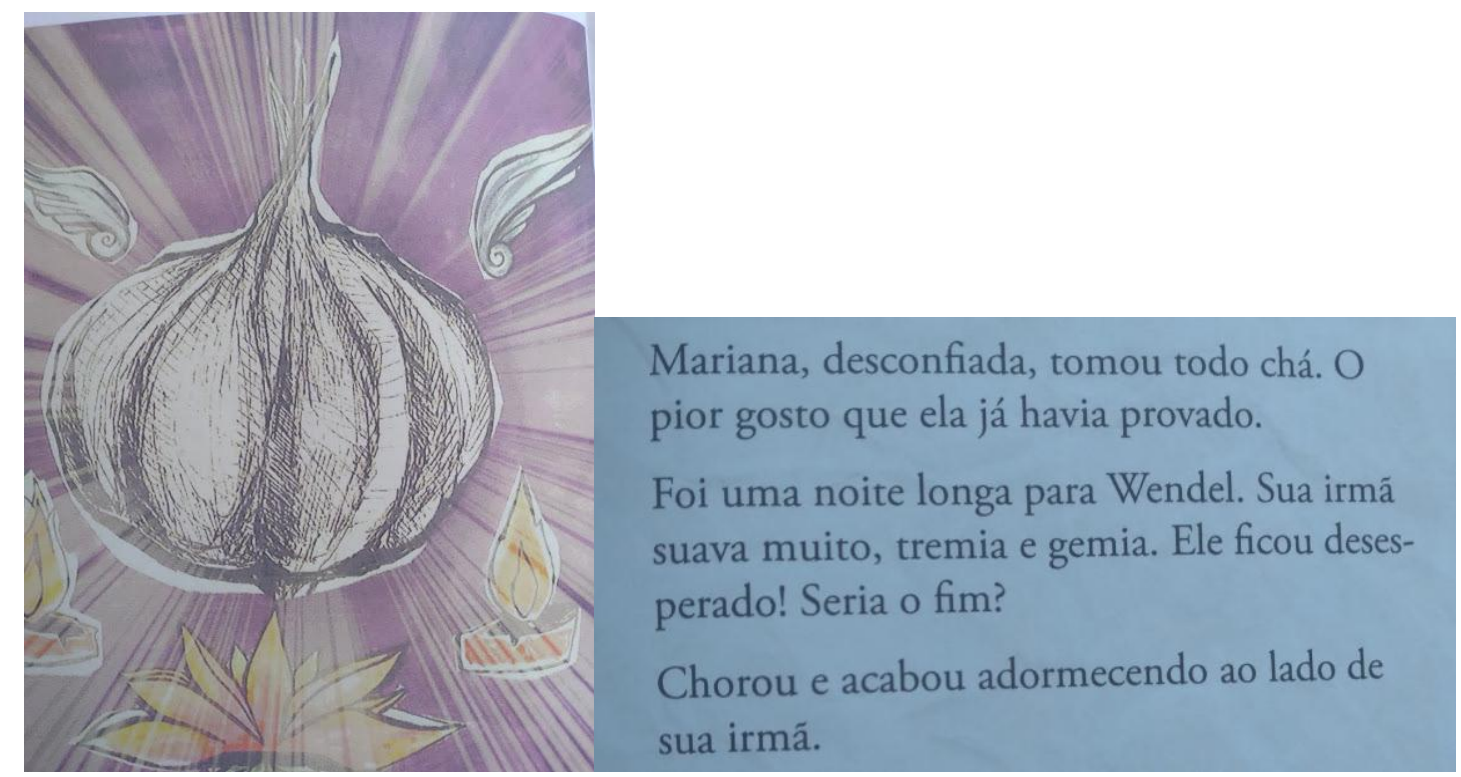

Figuras 11 e 12: ilustração e texto do livro $A$ cura.

Fonte: Disponível em: <https://bibliotecaterralivre.noblogs.org/editora/a-cura/> (p. $16 / 21)$.

A história de Wendel e Mariana nos mostra a cumplicidade e autonomia de duas crianças em busca da cura, enfrentando o perverso sistema de monetarização e evangelização da saúde. Juntos, encontram a cura a partir dos saberes tradicionais do uso de chás, aconselhados por um velho morador da região periférica em que moram. Esse inusitado livro nos apresenta a uma infância pouco narrada, pouco presente na literatura infantil, de uma vida autônoma no chão latino-americano. 
Retomando brevemente a discussão acerca da literatura menor, é pertinente salientar que:

Conceitualizar a literatura infantil como literatura menor, no sentido deleuzo-guattariano, implica interrogar se, apesar da filiação muitas vezes, explícita - a um projeto pedagógico que vincula o livro infantil à formação de cidadãos, a literatura infantil pode funcionar como imagem de devir, constituindo-se como potência, criação, algo que beira o impossível (Hillesheim, 2008, p. 3).

Nesse sentido, nossa escolha pelos livros escapa do entendimento das suas possíveis funções pedagógicas. Nos interessa a criação, esse impossível com o qual nos deparamos quando ao encontro de uma narrativa de infância estranha.

Em um contexto muito distinto, o livro $A$ rule is to break, publicado pela Maniac D Press, editora estadunidense em 2012 e escrito por John Seven e Jana Christy, explora uma narrativa mais individual. Investindo em um personagem único, "capetinha", os autores constroem um repertório sobre anarquismo para crianças.

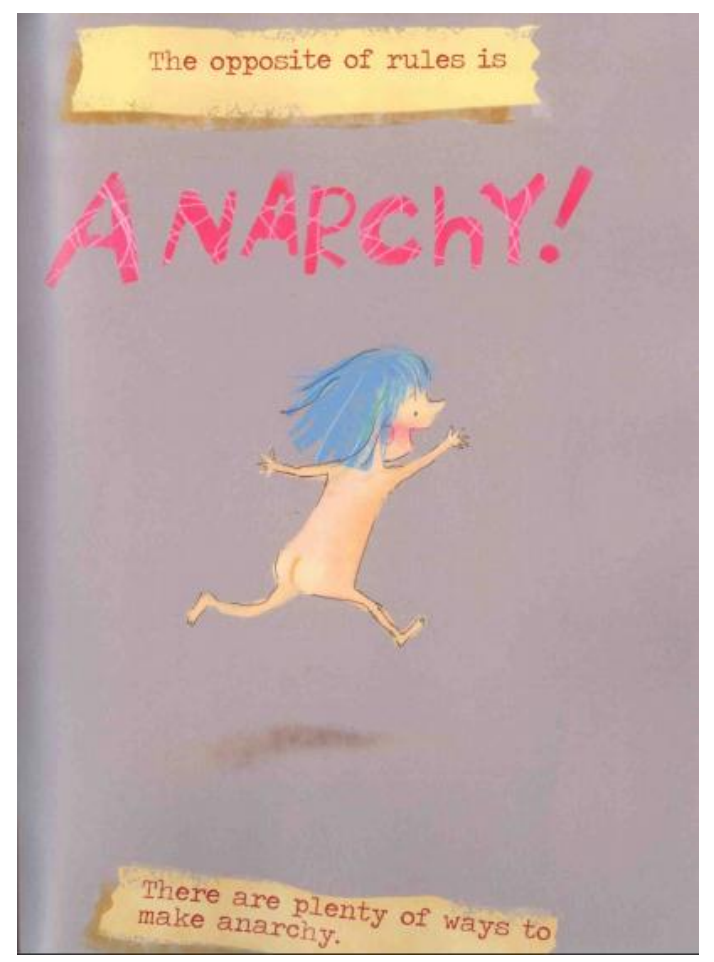

Figura 13: "O oposto das regras é anarquia! Há muitos jeitos de fazer anarquia" (tradução nossa).

Fonte: A rule is to break (2012).

O livro, que pode ser considerado bem menos ousado que o anterior, também se ocupa em desconstruir paradigmas impostos à infância. Apostando, principalmente, em ações relacionadas à autonomia, conceito muito presente nas discussões teórico-políticas do anarquismo, sendo uma postura de rejeição ao estigma do autoritarismo. 
Autonomia individual: o socialismo libertário vê no indivíduo a célula fundamental de qualquer grupo ou associação, elemento esse que não pode ser preterido em nome do grupo. A relação indivíduosociedade, no Anarquismo, é essencialmente dialética: o indivíduo, enquanto pessoa humana, só existe se pertencente a um grupo social - a ideia de um homem isolado da sociedade é absurda -; a sociedade, por sua vez, só existe enquanto agrupamento de indivíduos que, ao constituí-la, não perdem sua condição de indivíduos autônomos, mas a constroem. A própria ideia de indivíduo só é possível enquanto constituinte de uma sociedade. A ação anarquista é essencialmente social, mas baseada em cada um dos indivíduos que compõem a sociedade e voltada para cada um deles (GALLO, 2007, p. 21).

Então, uma vez que na relação indivíduo-sociedade é dialética, a autonomia individual torna-se um conceito muito caro ao anarquismo e é possível perceber essa articulação na obra $A$ rule is to break. A narrativa do livro explicita um posicionamento anti-capitalista, investindo em uma linguagem instigante, mas não pedagógica. Ainda que os autores chamem de "um guia infantil para anarquia", a obra não tem um sentido diretivo, de um manual propriamente dito. Contempla o universo lúdico a partir das ilustrações, focando em monstros e animais pouco convencionais, afastando-se das figuras estereotipadas.

Massoni (2012) discute acerca das ilustrações nos livros infantis, elencando argumentos sobre os recursos gráfico-visuais das histórias. A reflexão acerca dos personagens estereotipados é uma importante contribuição levantada pelo autor para articularmos com essa discussão, uma vez que estamos trabalhando com um material que se propõe a não validar conceitos colonizadores sobre a infância.

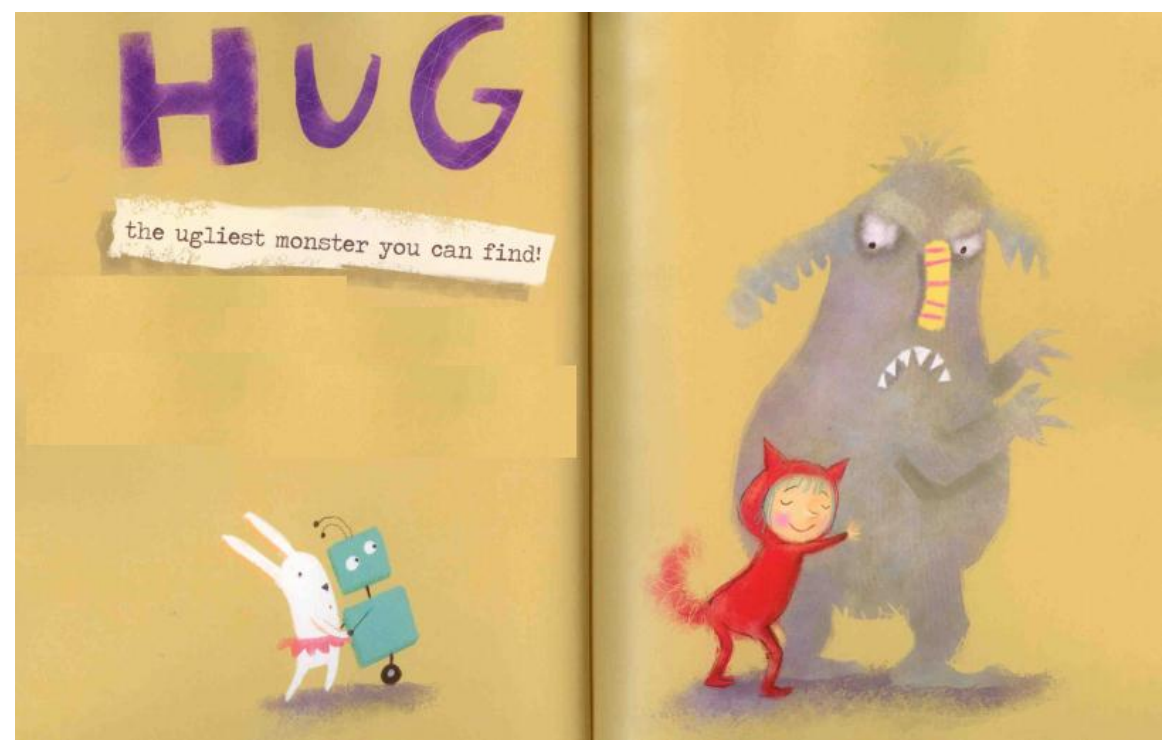

Figura 14: "Abrace o monstro mais feio que encontrar" (tradução nossa). Fonte: Acervo pessoal de Olivia Pires Coelho 
Walter Benjamin (1984) nos convida a pensar a literatura infantil como um espaço a ser restituído à criança, onde ela pode vivenciar o mágico, o lúdico, o social e político, sempre aproximando a criança do revolucionário. Nesse artigo, exercitamos a potência revolucionária da literatura infantil anarquista, especialmente a partir de um entendimento específico da revolução a partir das crianças e de suas narrativas, não a partir do possível adulto que residiria no "futuro" das crianças. As crianças, para Benjamin, entram nas histórias por meio da fantasia e se tornam cenógrafos e contadores de histórias.

Na obra inglesa Animal Squat, publicada pela editora Dog Section Press, escrita e ilustrada pelo coletivo DoubleWhy em 2019, aborda-se a questão das ocupações urbanas. A história, complexa, investe bastante tanto na linguagem escrita quanto na linguagem visual, possuindo textos longos e imagens coloridas. Aposta na ludicidade e no antropomorfismo, através do qual alguns animais são militantes pelo direito à cidade.

Narra a saga de um coletivo de animais que, sem moradia, ocupam o prédio de uma antiga fábrica de açúcar abandonada para construírem seu lar. O livro aborda, de forma extensa, ações que dialogam com o conceito anarquista de autogestão.

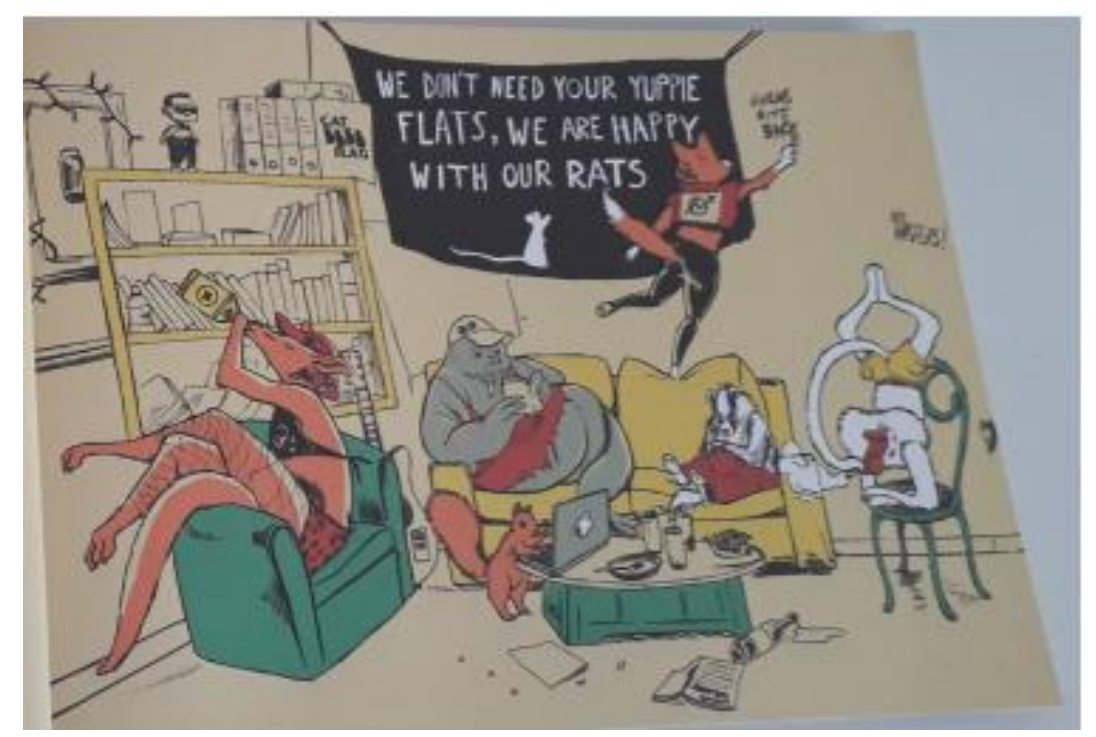

Figura 15: nessa página, a história conta, ao lado da seguinte ilustração: "o grupo era formado por um distinto grupo de animais: uma era uma artista e drag-queen, outro era um bípede fanático por livros, outro era um hacker de computadores anarquista, uma era uma transexual eco-ativista, outra era feminista de tempo integral e modelo em tempo parcial." (p. 10-11)

Fonte: Acervo pessoal de Olivia Pires Coelho

A história narra a resistência do grupo frente às investidas policiais para desapropriação do prédio abandonado que se tornou sua casa. Ainda que muito diferentes, os moradores se organizam para lutar contra o processo de despejo que se desenrola. Apostando em uma organização horizontal e autogestionária, ou seja, sem líderes ou superiores, a história acompanha a articulação deste distinto grupo. 
Autogestão social: Em decorrência do princípio de liberdade individual, o anarquismo é contrário a todo e qualquer poder institucionalizado, contra qualquer autoridade e hierarquização e qualquer forma de associação assim constituída. Para os anarquistas a gestão da sociedade deve ser direta, fruto dela própria, o que ficou conhecido como autogestão (GALLO, 2007, p. 20).

Abordam questões também pouco ou nada trabalhadas na infância, como repressão policial, transsexualidade, recusa ao modelo de trabalho capitalístico e ocupação de prédios públicos para moradia. Podemos perceber que a literatura infantil anarquista traz à tona discussões presentes no cotidiano das crianças, mas invisibilizadas em seus livros. Segundo o Relatório lançado pelo Programa das Nações Unidas para Assentamentos Humanos, no Brasil há cerca de 6,9 milhões de famílias sem moradia7 e, mesmo assim, a questão não é retratada na literatura para crianças. Como se não fosse "assunto de criança" ou, ainda, como se as crianças não tivessem capacidade de discutir tal temática.

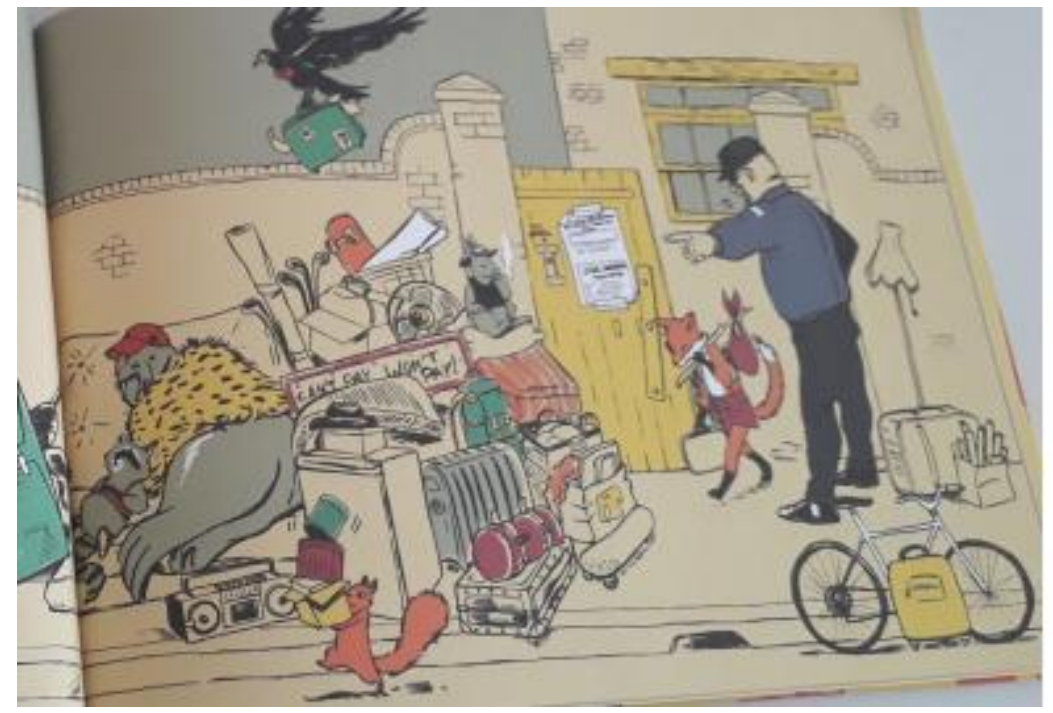

Figura 16: cenas do despejo dos animais com a reintegração de posse do imóvel abandonado

Fonte: Acervo pessoal de Olivia Pires Coelho

O livro narra o movimento de resistência dos animais e desenvolve uma crítica anticapitalista contundente: "mas será que eles se cansam de viver assim? Com certeza, sim. Mas eles preferem esse cansaço ao invés do cansaço diário de trabalhar constantemente para aumentar a riqueza de outra pessoa. Eles não se importam nem um pouco com riqueza! Tudo que querem é tempo e espaço para serem quem eles são: criaturas selvagens!" (Animal Squat).

A escolha desses materiais por parte dos autores, parte do entendimento de que política é coisa de criança, sim. Parte também do comprometimento político em produzir

\footnotetext{
7 Fonte: https://g1.globo.com/economia/noticia/brasil-tem-69-milhoes-de-familias-sem-casa-e-6-milhoes-deimoveis-vazios-diz-urbanista.ghtml
} 
literatura infantil de qualidade, em divulgar esse material e trabalhar ativamente na difusão de conteúdos para criação de um repertório político que rompa as barreiras do adultocentrismo e da adultocracia. A produção deste tipo de literatura infantil implica naquele tipo de trabalho que Schérer e Hocquenguem (1976) denominaram um "ir junto" com as crianças, uma produção coletiva na qual crianças e adultos, em um exercício de horizontalidade nas relações, produzem coletivamente ${ }^{8}$. Um aprender coletivo, um ensinar coletivo, ambos múltiplos e não referenciados exclusivamente nos adultos, apostando no coletivo e em seus deveres como possibilidades de criação.

\section{Conclusão: pré-manifesto anarquista anti-adultocêntrico}

Esse artigo discutiu questões sobre a literatura à luz de autores como Deleuze, Benjamin e atravessou diversos autores anarquistas (Allan de Freitas, Federico Zenoni, John Seven, Jana Christy, DoubleWhy), além da abordagem conceitual específica da literatura para crianças. Como lente metodológica, lançou mão de relatos de casos de práticas anarquistas em educação. Percorremos a apropriação da literatura infantil pelo anarquismo, enquanto um movimento de renovação e reestruturação de paradigmas patriarcais e adultocêntricos.

Fechamos esse processo germinando, cada vez mais, as sementes do combate à hegemonia do pensamento adulto na literatura. Os anarquistas estão interessados na produção de novos modos de vida instaurados no presente. O tempo presente é composto por todos: crianças, jovens, adultos, idosos. A luta é por uma vida liberta, para todos e todas. A criação de estruturas para receber os mais jovens no mundo e na luta por um mundo novo é parte essencial dessa invenção de novas sociabilidades. Crianças não são o futuro de nenhum país, como tentam forjar os slogans governamentais de educação. Crianças podem ser fagulhas explosivas de instauração do novo no presente. Fazer gemer a gramática oficial, produzir polilinguismos que produzam rachaduras no que acreditamos como verdadeiro e real.

Servir-se do polilinguismo em sua própria língua, fazer desta um uso menor ou intensivo, opor o caráter oprimido dessa língua a seu caráter opressivo, achar os pontos de não cultura e de subdesenvolvimento, as zonas de terceiro mundo linguísticas por onde uma língua escapa, um animal se enxerta, um agenciamento se instala (DELEUZE E GUATTARI, 1977, p. 53).

Então, se o mundo adulto ainda acredita que o mundo infantil é um terceiro mundo a ser colonizado, se o homem adulto acredita que as crianças vivem na selvageria animal

${ }^{8}$ Para uma exploração do tema do "ir junto" no campo educativo, consultar: GALLO, 2019. 
desenfreada, se o controle gramatical do professorado ainda acredita que é na ode à ordem que se deve tratar as crianças, são nestas brechas que devemos afirmar a vida nova, afirmar que somos animais selvagens, que somos o descontrole encarnado, que somos a resistência à colonização! Afirmar a vida nova, em crianças e em adultos, na verve anarquista dos livros!

\section{Referências}

ABRAMOVICH, F. Literatura infantil: gostosuras e bobices. São Paulo: Editora Scipione, 2006.

ADICHIE, C. N. O perigo de uma história única. São Paulo: Companhia das Letras, 2019.

BARTHeS, R. Aula. Tradução de Leyla Perrone Moisés. São Paulo: Ed. Cultrix, 1978.

BENJAMIN, W. Reflexões: a criança, o brinquedo, a educação. São Paulo: Summus, 1984.

COSTA, D. W. S.; BRITO, M. R. A literatura e a vida: entre Deleuze e Caio Fernando Abreu. Sociopoética. Campina Grande, n. 20, v. 2, 2018.

DELEUZE, G. Crítica e Clínica. Tradução de Peter Pál Pelbart. São Paulo: Editora 34, 1997.

DELEUZE, G.; GUATTARI, F. Kafka - por uma literatura menor. Tradução: Júlio Castañon Guimarães. Rio de Janeiro: Imago Editora, 1977.

GALLO, S. Pedagogia Libertária: anarquistas, anarquismos e educação. Editora Imaginário e Editora da Universidade Federal do Amazonas, 2007.

GALLO, S. Educação Infantil: do dispositivo pedagógico ao "ir junto" com as crianças. In: ABRAMOWICZ, A.; TEBET, G. G. C. (org.). Infância e pós-estruturalismo. $2^{a}$ ed. São Carlos: Pedro \& João Editores, 2019, p. 113-130.

HILLESHEIM, B. Por uma literatura menor: produção literária para a infância. Reflexão e Ação, Santa Cruz do Sul, v. 16, n. 2, p. 38-50, mar. 2009

MASSONI, L. F. H. Ilustrações em livros infantis: alguns apontamentos. D.A Pesquisa, Florianópolis, v. 7, n. 9, p. 121-129, 2018.

OLIVEIRA, L. C. C. Deleuze e a literatura: o devir pelas linhas da escrita. Dissertação (Mestrado) - Universidade do Estado do Rio de Janeiro, Instituto de Filosofia e Ciências Humanas. 2010.

ROSA, R. Espaços para crianças nas Feiras Anarquistas. Revista da Biblioteca Terra Livre, Ano II - Número 3 (10 semestre de 2015).

ROSEMBERG, F. Educação para quem? Ciência e Cultura, São Paulo, v. 28, n. 12, p. 1466-1471, 1976.

SANTIAGO, F. FARIA, A. L. G. Para além do adultocentrismo: Uma outra formação docente descolonizadora é preciso. Educação e Fronteiras On-Line, Dourados/MS, v.5, n.13, p.72-85, jan./abr. 2015. 
SILVA, A. L. Trajetória da literatura infantil: da origem histórica e do conceito mercadológico ao caráter pedagógico na atualidade. REGRAD - Revista Eletrônica de Graduação do UNIVEM. São Paulo: 2009.

SCHÉRER, R. HOCQUENGHEM, G. "Co-Ire": album systématique de l'enfance. Revue Recherches, n० 22, 1976.

\footnotetext{
i Professor Titular da Faculdade de Educação da Unicamp. Licenciado em Filosofia, mestre e doutor em Educação, com livre docência em Filosofia da Educação. Pesquisador 1B do CNPq. Seus campos de pesquisa são atravessados pelo Anarquismo e pela Filosofia Francesa Contemporânea. Atualmente, dedica-se a pensar a infância e suas potências descolonizadoras.
}

ii Estudou Geografia (UFAM) e Pedagogia (UFRGS), é mestre em Educação - Estudos sobre Infâncias (UFRGS) e atualmente cursa o Doutorado em Educação na UNICAMP com financiamento CAPES/DS. É anarquista e articula, desde 2011, espaços coletivos para crianças no contexto de movimentos sociais e organizações políticas. Militante do movimento materno, também é ativista pelo direito à participação infantil e pelo reconhecimento de bebês e crianças pequenas como sujeitos ativos na sociedade. Participa de Coletivos feministas e de Educação Popular. Desenvolve pesquisas, publica artigos e comunicações nas áreas de Infância e Anarquismo, Descolonização e Geografia da Infância.

iii Doutorando em Educação (Universidade de Campinas, Brasil). Mestre em Educação (Universidade Federal de São Paulo, Brasil, 2017). Bacharel em Ciências Sociais (Pontifícia Universidade Católica de São Paulo, Brasil, 2013) e Técnico em Artes Cênicas (Instituto de Artes e Ciências, Brasil, 2008). Publicou os livros de poemas Cretino (Ed. Patuá, 2013) e Duna (Ed. Patuá, 2018). Atualmente é membro do Transversal e LIMA (Laboratório Insurgente de Máquinas Anarquistas), ambos grupos de pesquisa da Universidade de Campinas, e organiza a FLIPEI - Festa Literária Pirata das Editoras Independentes.

iv É dramaturgo e professor de teatro. Mestrando em Educação pela FE-Unicamp. Graduado em Arte-Teatro pelo IA-Unesp. Desenvolve pesquisa sobre teatro, educação e pedagogia do teatro, com ênfase em Teatro Político, Pedagogia Libertária, e o Teatro Social anarquista no território brasileiro.

Como citar esse artigo:

GALLO, Sílvio Donizetti de Oliveira; COELHO, Olivia Pires Coelho; LIMONGELLI, Rafael Moraes; MENDES, Renato. Anarquismo e infância: a literatura anarquista para crianças.

Revista Digital do LAV, Santa Maria: UFSM, v. 14, n. 2, p. 187-207, mai./ago. 2021. 